\title{
Peningkatan Keterampilan Dasar Mengajar Mahasiswi PGPAUD pada Kelas Microteaching Melalui Metode Drill and Practice
}

\author{
Srikandi Octaviani $^{*}$, Ika Wulandari Utamining Tias ${ }^{2}$ \\ ${ }^{1}$ Pendidikan Guru Pendidikan Anak Usia Dini, STKIP PGRI Metro \\ ${ }^{2}$ Pendidikan Guru Sekolah Dasar, Universitas Lampung \\ Email: vetwesto@gmail.com
}

Received: August 22, 2021

Accepted: January 4, 2022

Published: January 4, 2022

\begin{abstract}
Microteaching is a compulsory subject taken by students of program study PG PAUD semester $V I$. The purpose of this activity is to improve understanding and basic skills of teaching PAUD students in Microteaching classes using drill and practice methods. The research method used in this research is Classroom Action Research, there are 4 stages in this activity, namely: planning, action, observation and reflection. The data collection technique used an observation technique using an observation sheet related to eight basic teaching skills and the data analysis technique used was descriptive qualitative. The results of this research in the practice session of cycle II there was an increase in almost all female students who succeeded and were able to apply the eight basic teaching skills in their teaching practice, only a few who had not succeeded because they could not control time, were still nervous and this could be overcome with a lot of work practice, and still having difficulty in choosing the right language and easy to understand for early childhood. Recommendations from this research are aimed at educational stakeholders where this increase occurs because of the training process (practice) that occurs repeatedly and the evaluation or reflection of each student who appears, there are real and direct examples of being able to develop every aspect of basic teaching skills in each student.
\end{abstract}

Keywords: Drill and practice methods, basic skills teaching, microteaching, PAUD, practice

Abstrak: Microteaching merupakan mata kuliah wajib yang ditempuh oleh mahasiswi PG PAUD semester VI. Tujuan dari kegiatan ini adalah untuk meningkatkan pemahaman dan keterampilan dasar mengajar mahasiswi PAUD dalam kelas Microteaching menggunakan metode drill and practice. Metode penelitian yang digunakan dalam penelitian ini adalah Penelitian Tindakan Kelas ada 4 tahap dalam kegiatan ini, yaitu: perencanaan (planning), tindakan (action), pengamatan (observation) dan refleksi (reflection). Teknik pengumpulan data menggunakan teknik observasi menggunakan lembar observasi terkait delapan keterampilan dasar mengajar dan teknik analisis data yang digunakan adalah deskriptif kualitatif. Hasil penelitian ini pada sesi praktik siklus II terjadi peningkatan hampir semua mahasiswi berhasil dan mampu menerapkan delapan keterampilan dasar mengajar dalam praktik mengajarnya, hanya beberapa yang belum berhasil karena belum bisa mengontrol waktu, belum PD dan hal ini bisa di atasi dengan banyak latihan, serta masih kesulitan dalam pemilihan bahasa yang tepat dan mudah dipahami anak usia Dini. Rekomendasi dari penelitian ini ditujukan pada stakeholder pendidikan dimana peningkatan ini terjadi karena adanya proses latihan (praktik) yang terjadi secara berulang dan adanya evaluasi atau refleksi dari setiap mahasiswi yang tampil, adanya contoh nyata dan langsung mampu mengembangkan setiap aspek keterampilan dasar mengajar pada masing-masing mahasiswi.

Kata Kunci: Drill and practice, keterampilan dasar mengajar, microteaching, PAUD, praktik

DOI: $\underline{\text { http://dx.doi.org/10.23960/pdg.v9i2.22786 }}$ 


\section{PENDAHULUAN}

Microteaching atau pembelajaran mikro merupakan salah satu mata kuliah wajib yang ditempuh oleh mahasiswa-mahasiswi jurusan pendidikan dan keguruan termasuk mahasiswi program studi (Prodi) Pendidikan Guru Pendidikan Anak Usia Dini (PG PAUD) semester VI. Mata kuliah (MK) microteaching wajib ditempuh oleh mahasiswa sebelum mengambil MK Program Praktik Lapangan (PPL) pada semester berikutnya. Menurut Shoffa, microteaching dapat diartikan sebagai model pelatihan guru/ calon guru untuk menguasai keterampilan dasar mengajar tertentu melalui proses pengajaran yang sederhana (S. Shoffa, 2016). Helmiati menambahkan melalui proses latihan dalam microteaching inilah pengetahuan, sikap dan keterampilan yang diperoleh selanjutnya dikembangkan melalui PPL di sekolah-sekolah dibawah pengawasan kepala sekolah, guru pamong dan supervisor atau pembimbing PPL (Helmiati, 2013).

Pembelajaran Mikro merupakan sebuah model pembelajaran yang dikecilkan, jumlah pesertanya berkisar antara 5 sampai 10 orang mahasiswa calon guru, ruang kelasnya terbatas, waktu pelaksanaannya berkisar antara 10 sampai 15 menit, terfokus pada keterampilan mengajar tertentu, dan pokok bahasanya disederhanakan (Mansyur, 2017). Pembelajaran mikro atau pembelajaran kelas kecil ini bertujuan untuk melatih kemampuan mahasiswa dalam mengajar termasuk mempersiapkan mental sebelum terjun ke lapangan dan mengajar dalam skala besar atau kelas yang sebenarnya. Karena pada dasarnya menjadi seorang pendidik atau guru harus melalui proses pembentukan yaitu belajar dan berlatih hingga bisa terbentuk individu yang siap mencerdaskan generasi penerus. 
Kemampuan mahasiswa dapat dilatih dan diasah melalui pembelajaran mikro, melatih diri untuk menerapkan apa yang telah didapat selama ini di bangku kuliah, mengasah keterampilan berbicara di depan kelas agar kelak terlatih berbicara di depan umum dan menghadapi forum, berlatih bagaimana menyampaikan materi agar jelas dan dapat diterima oleh peserta didik sehingga tujuan pembelajaran dapat tercapai, serta berlatih mengelolah kelas dan menciptakan suasana belajar yang menyenangkan, dan berbagai skill atau keterampilan lainnya yang nantinya akan melekat pada diri dan menjadi sebuah profesi yaitu guru (pendidik).

Helmiati mengungkapkan pembelajaran mikro bertujuan membekali calon tenaga pendidik dengan beberapa keterampilan dasar mengajar (Helmiati, 2013). Bagi calon tenaga pendidik metode ini akan memberi pengalaman mengajar yang nyata dan kesempatan berlatih sejumlah keterampilan dasar mengajar secara terpisah dan bertahap. Selain itu, pembelajaran mikro dimaksudkan untuk memberikan pemahaman kepada calon pendidik tentang kapan dan bagaimana menerapkan berbagai keterampilan dasar mengajar tersebut dalam proses pembelajaran.

Dalam kelas microteaching ini, mahasiswi diminta untuk menguasai delapan keterampilan dasar mengajar yang harus dimiliki guru atau calon pendidik yaitu: keterampilan membuka dan menutup pelajaran, keterampilan bertanya, memberi penguatan, mengadakan variasi, keterampilan menjelaskan, membimbing diskusi kelompok kecil, mengelolah kelas dan mengajar kelompok kecil serta perorangan. Semua keterampilan dasar mengajar tersebut memiliki konsep dan keterampilan yang berbeda satu sama lainnya dan semuanya memerlukan penguasaan mendalam dengan banyak latihan dan praktik nyata bukan sekedar pemahaman dengan dihafal seperti materi-materi lainnya. Penguasaan Keterampilan dasar mengajar dapat membekali guru atau calon 
pendidik dalam menyampaikan materi pelajaran agar tujuan pembelajaran dapat tercapai dan materi dapat diterima baik oleh siswa.

Menurut Asia, kualitas guru sebagai gambaran kemampuan dan keterampilan dalam melaksanakan tugas profesinya, membuahkan kualitas pendidikan dan pengajaran dengan kata lain keterampilan dasar mengajar bagi guru dapat mengantarkan ke arah keberhasilan proses pendidikan dan pengajaran, baik bagi guru maupun siswa dalam kegiatan belajar mengajar (Asia, 2019). Selain itu Elprida, dkk menambahkan bahwa keterampilan dasar mengajar guru merupakan kemampuan minimal dalam kegiatan atau aktivitas yang kompleks namun masih saling berkaitan yang harus dimiliki tenaga pendidik profesional (guru) untuk menunjang pembelajaran anak (Elprida et al., 2018). Selain itu Rusmaini juga menambahkan Keterampilan dasar mengajar merupakan salah satu penentu keberhasilan pembelajaran (Rusmaini, 2019). Keterampilan ini selain dapat digunakan oleh pendidik tetapi dapat juga digunakan oleh calon pendidik (peserta didik). Namun jika dilihat pada kenyataannya banyak para guru mengajar dan mengabaikan keterampilan - keterampilan yang sangat mendasar ini.

Selain itu, dalam kelas microteaching ini juga mahasiswa diharapkan dapat menyusun Rencana Pelaksanaan Pembelajaran Harian (RPPH) yaitu sebuah acuan untuk mengelolah kegiatan bermain dalam satu hari yang sesuai dengan user (penggunanya) yaitu peserta didik, kemudian mahasiswa dapat melakukan evaluasi atau refleksi diri terhadap pembelajaran yang telah disampaikan tujuannya agar calon guru dapat mengetahui kekurangan atau kesalahan yang dilakukan selama pembelajaran agar dapat diperbaiki kedepannya. Hal ini senada dengan yang diungkapkan Shoffa bahwa baik guru maupun calon guru dapat memperoleh informasi tentang kekurangan dan kelebihannya 
dalam mengajar serta dapat mencoba metode atau model serta media pembelajaran baru yang nantinya dapat diterapkan di kelas sebenarnya (S. Shoffa, 2016).

Wahyulestari mengungkapkan bahwa keberhasilan mengajar, selain ditentukan oleh faktor kemampuan, motivasi, dan keaktifan peserta didik dalam belajar dan kelengkapan fasilitas atau lingkungan belajar, juga akan tergantung pada kemampuan guru dalam mengembangkan berbagai keterampilan mengajar (M. R. Wahyulestari, 2018). Keterampilan-keterampilan ini sudah sepantasnya dikuasai guru atau calon pendidik sebagai bekal menghadapi perilaku anak yang benar-benar unik. Aida menambahkan calon guru, harus mampu menguasai keterampilan mengajar karena hal tersebut merupakan bekal mahasiswa sebagaicalon guru untuk menjadi seorang tenaga pendidik yang professional (Aida, 2019). Jadi, pada kelas Microteaching ini tidak sebatas tahu keterampilan apa saja yang harus dikuasai seorang guru dan calon pendidik tapi juga dapat menerapkannya di dalam kelas pada setiap pembelajaran dan dimulai dari kelas kecil microteaching.

Semester genap yang dimulai dari bulan maret 2021 ini Indonesia masih menghadapi masalah pandemic covid-19. Hal ini berdampak pada system pembelajaran tatap muka di kampus, dimana ketua mengeluarkan kebijakan bahwa tatap muka di lakukan 1x setiap bulan dan 3x dilakukan pembelajaran secara online atau daring. Karena keterbatasan jumlah tatap muka ini maka penyampaian materi dilakukan secara daring dan untuk praktiknya memanfaatkan jam tatap muka agar dapat memberikan pengalaman nyata kepada mahasiswi dalam praktik mengajar sekaligus melatih mental mereka berdiri di depan kelas dan menyampaikan materi, termasuk mengatasi hambatan atau masalah didalam kelas ketika proses pembelajaran berlangsung. 
Awal pembelajaran materi disampaikan melalui aplikasi zoom dan materi juga dibagikan pada aplikasi whatsapp karena ada beberapa mahasiswi yang terkendala sinyal sehingga tidak bisa bergabung di zoom dan diskusi serta tanya jawab dilanjutkan di-chat room whatsapp, agar semua mahasiswi dapat terlibat langsung dalam diskusi dan Tanya jawab. Dari 32 mahasiswi PG-PAUD Semester VI, hampir sebagiannya adalah guru di TK atau PAUD di daerah masing-masing dan memilih melanjutkan pendidikan Guru PAUD untuk memperoleh gelar S1, sebagian lagi adalah mahasiswi murni lulusan SMA sederajat. Intinya sebagian mahasiswi ini sudah memiliki pengalaman mengajar di PAUD, bukan hanya 1-2 semester bahkan ada yang sudah mengajar selama bertahuntahun, bahkan beberapa diantaranya adalah pendiri PAUD.

Namun pada saat tatap muka pertama yang dijadwalkan adalah praktik mengajar dimana beberapa mahasiswi akan berperan sebagai guru secara bergantian sedangkan mahasiswi lainnya akan berperan sebagai Peserta didik dan dibebaskan untuk bertingkah layaknya seperti anak PAUD. Pada pertemuan awal ini mahasiswi diminta mengajar selama 10-20 menit dan menyisipkan keterampilan dasar mengajar. Hasilnya dari 6 orang mahasiswi yang tampil menjadi guru hanya 2 yang mampu menyisipkan keterampilan dasar mengajar. Padahal materi keterampilan dasar mengajar sudah disampaikan dalam pembelajaran online juga sudah didiskusikan bersama-sama. Dari sana terlihat bahwa pemahaman mahasiswi masih kurang termasuk mahasiswi yang telah mengajar di TK atau pun PAUD. Karena pada setiap calon guru selesai yang perform mahasiswi lain diminta memberikan komentar baik saran maupun kritik, tapi hanya sedikit yang mampu berkomentar terkait keterampilan dasar mengajar. Melihat tersebut maka di dalam kelas ini perlu adanya peningkatan pemahaman keterampilan dasar mengajar pada para mahasiswi. 
Maka tujuan dari kegiatan ini adalah untuk imeningkatkan keterampilan dasar mengajar mahasiswi PAUD semester VI dalam kelas Microteaching menggunakan metode drill and practice. Metode drill and practice adalah suatu metode pembelajaran yang dapat membantu dalam memahami setiap langkah pengajaran yang sesuai dengan kebiasaanyang diajarkan secara berulang-ulang (Nasirun et al., 2020).

\section{METODE}

Metode penelitian yang digunakan dalam penelitian ini adalah Penelitian Tindakan Kelas atau Classroom Action Research, Penelitian Tindakan Kelas ini merupakan salah satu upaya untuk memperbaiki dan meningkatkan mutu pembelajaran di kelas khususnya pada mata kuliah Microteaching. Ada 4 tahap dalam kegiatan ini, yaitu: perencanaan (planning) meliputi identifikasi masalah, menyusun perangkat pembelajaran dengan menerapkan metode drill and practice, tindakan (action) meliputi kegiatan praktik (latihan) para mahasiswa dengan metode drill and practice dalam menerapkan dan meningkatkan penguasaan mereka terhadap delapan keterampilan dasar mengajar, pengamatan (observation) yaitu melakukan pengamatan atas setiap performance mahasiswa saat praktik dan melakukan penilaian serta evaluasi dari setiap tampilan mereka sebagai bahan perbaikan untuk praktik selanjutnya dan refleksi (reflection) yaitu merespon kegiatan praktik (latiham) mahasiswa dalam setiap praktiknya. Subjek penelitian tindakan kelas ini adalah mahasiswi S1 Program studi Pendidikan Guru PAUD semester VI sebanyak 32 orang TA. 2020-2021. Teknik pengumpulan data menggunakan teknik observasi menggunakan lembar observasi terkait delapan keterampilan dasar mengajar yang harus dikuasai mahasiswa dan teknik analisis data yang digunakan adalah deskriptif kualitatif. Untuk keberhasilan atau peningkatan pemahaman keterampilan 
dasar mengajar setelah proses pembelajaran dilakukan dengan cara memberikan evaluasi dan refleksi dari setiap tampilan mahasiswi seusai praktik mengajar di kelas mikro.

\section{HASIL DAN PEMBAHASAN}

Microteaching bertujuan untuk membekali para mahasiswi dengan keterampilan dasar mengajar yang nantinya akan diterapkan dalam dunia mengajar yang sesungguhnya, selain itu kelas microteaching ini juga bertujuan meningkatkan performance dari masing-masing mahasiswi agar lebih percaya diri, siap dan berani terjun ke lapangan, siap menghadapi peserta didik, tantangan dunia kerja serta siap menghadapi permasalahan dalam proses mengajar nantinya. Menurut Rusmaini, guru harus memiliki keterampilan dasar mengajar agar dapat menciptakan pembelajaran yang kreatif, efektif dan menyenangkan (Rusmaini, 2019). Adnyana menambahkan bahwa pada hakikatnya keterampilan mengajar merupakan seluruh aktivitas guru di kelas dan tugas guru yang spesifik (Adnyana, 2018).

Berdasarkan pernyataan tersebut jelas bahwa setiap guru atau calon guru harus mampu menguasai keterampilan dasar mengajar agar mampu menciptakan pembelajaran yang menarik, menyenangkan serta menjadi guru yang mampu memotivasi dan mengispirasi para peserta didiknya, dengan demikian tujuan pembelajaran lebih mudah tercapai. Microteaching memberikan kepada calon guru (mahasiswa) untuk membentuk mental diri menjadikan guru sebagai profesi sepenuh hati, dan juga sebagai sarana umpan balik dalam setiap performance-nya.

Latihan dan pengalaman mengajar sangat diperlukan bagi setiap pendidik, karena semakin banyak latihan dan pengalaman semakin terbentuk mental mendidiknya. Melalui kelas microteaching ini juga terjadi umpan balik, disinilah setiap calon guru 
akan mengetahui kelemahan dan kekuranganya dan dapat dilakukan perbaikan kedepannya. Hal ini terbukti dari 6 orang mahasiswi yang perform pada tatap muka pertama, hanya 2 orang yang mampu menyisipkan keterampilan dasar mengajar, sedangkan sisanya bahkan ada yang tidak siap untuk perform, masih menganggap kegiatan ini sebagai permainan dalam artian tidak menempatkan diri selayaknya tidak sebagai guru atau peserta didik, ada yang mengajar tidak sesuai dengan RPPH yang telah di rancang, ada yang tidak membawa alat peraga atau APE (Alat Permainan Edukatif) dan ada pula yang membawa APE tapi justru tidak digunakan dalam praktik mengajarnya, ditambah mahasiswi yang memberi komentar terkait keterampilan dasar mengajar baru sedikit.

Hal ini menunjukkan bahwa masih kurangnya pemahaman mahasiswi terkait konsep keterampilan dasar mengajar serta penyampaian materi yang disampaikan melalui virtual menyebabkan adanya salah pemahaman. Hal ini di tunjukan pada hasil performance pertama mahasiswi PAUD pada Gambar 1.

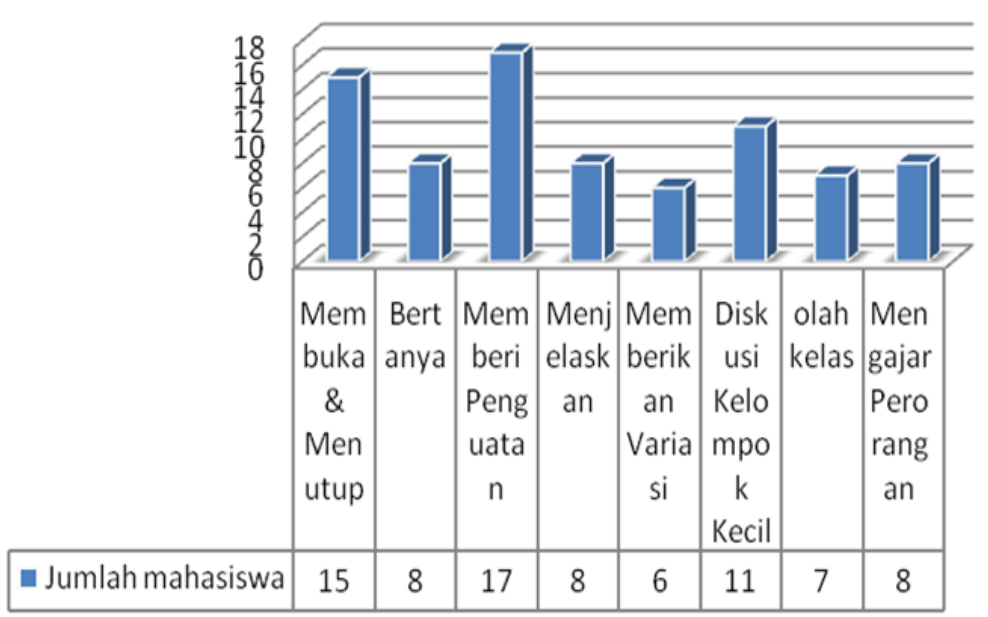

Gambar 1. Hasil Praktik I Microteaching Keterampilan Dasar Mengajar Mahasiswi PAUD

Berdasarkan Gambar 1, dilihat bahwa dari 8 keterampilan dasar mengajar hanya keterampilan memberi penguatan yang bisa diterapkan lebih dari setengah jumlah 
mahasiswi yaitu sebanyak 17 orang, padahal memberi penguatan termasuk kategori paling mudah untuk diterapkan tapi masih banyak mashasiswi yang tidak menerapkannya saat penampilan pertama.

Keterampilan membuka dan menutup pelajaran telah diterapkan oleh 15 orang, kebanyakan mahasiswi lupa membuka kelas tapi langsung masuk pada pembelajaran dan ada pula yang tidak sampai menyimpulkan kegiatan hari itu hanya sebatas mengakhir pekerjaan peserta didik. Untuk keterampilan mengelolah diskusi kelompok kecil dilakukan oleh 11 orang ini termasuk keterampilan yang cukup sulit diterapkan karena guru harus fokus pada beberapa kelompok kecil peserta didik dan harus membagi rata perhatiannya pada semua kelompok sayang banyak mahasiswi yang gagal karena terlalu fokus pada kelompok tertentu atau justru sama sekali tidak membentuk kelompok kecil. Dan untuk keterampilan lainnya harus banyak peningkatan baik dalam pemahaman juga penerapannya.

Menurut Rusmaini, kemampuan dasar mengajar merupakan suatu keahlian yang harus dimiliki oleh guru dalam memberikan penjelasan materi, mengelola kelas, serta keterampilan guru dalam memberikan variasi pembelajaran (Rusmaini, 2019). Dengan demikian seorang pengajar harus mempersiapkan diri dan bahan-bahan yang diperlukan untuk mengajar. Persiapan tersebut antara antara lain materi dan bahan ajar, media pembelajaran, serta cara guru dalam mengelola dan menguasai kelas.

Saat praktik setiap penampilan dari masing-masing mahasiswi tersebut mendapat masukan tujuannya adalah untuk memperbaiki dan meningkatkan pemahaman mereka mengenai keterampilan dasar mengajar, karena penyampaian materi di iringi dengan latihan dan praktik membuat pemhaman atas materi tersebut lebih mudah dipahami karena disertai dengan contoh nyata dan disnilah metode drill and performance 
diterapkan. Karena seperti dijelaskan sebelumnya bahwa metode drill and performance merupakan pembelajaran yang dapat membantu memahami setiap langkah pengajaran yang sesuai dengan kebiasaan yang diajarkan dan diterapkan secara berulang-ulang dengan latihan sehingga memperoleh keteramilan yang diharapkan. Bisa jadi para mahasiswi tersebut telah hafal dan tahu apa saja bagian dari keterampilan dasar mengajar tersebut tapi tidak tahu bagaimana mengaplikasikannya dalam praktik mengajar.

Keterampilan membuka dan menutup pelajaran bisa dimulai dengan membaca doa, atau mengajak peserta didik melakukan pemanasan otak (brainstorming) dengan bergerak melompat dan bertepuk tangan di tempat, atau menyapa dan bertanya kepada peserta didik mengenai apa yang mereka lakukan sebelum datang ke sekolah atau masuk ke kelas atau pertanyaan lain terkait tema yang akan di ajarkan yang tujuannya mengarahkan peserta didik pada kegiatan yang akan dilakukan, karena perhatian peserta didik di awal pertemuan akan menentukan keberhasilan pencapaian tujuan pembelajaran, dan keterampilan menutup pelajaran dengan mengajak peserta didik menyimpulkan apa yang telah dilakukan pada hari itu ini bertujuan memberikan gambaran menyeluruh mengenai pencapaian yang telah dipelajari dan memberi motivasi atau pesan moral pada peserta didik terkait dengan tema. Sayangnya pada hanya 15 orang yang mampu menerapkan keterampilan ini, sisanya ada yang langsung memulai pembelajaran dengan alasan takut kehabisan waktu dan ada pula yang lupa menyimpulkan karena telah kehabisan waktu dan lupa.

Keterampilan bertanya digunakan guru atau calon pendidik untuk mengetahui sejauh mana minat atau pengetahuan peserta didik atas tema yang diajarkan dan bisa juga untuk mendapat jawaban atau balikan dari peserta didik, misal pada tema anggota tubuh guru 
bisa bertanya apa saja bagian anggota tubuh dan meminta peserta didik menyebutkannya, apa yang dilakukan untuk menjaga kesehatan anggota tubuh, dan sebagainya. Dalam hal ini hanya 8 orang calon guru yang menerapkannya dengan cara menggabungkannya dengan keterampilan membuka dan menutup pelajaran dan ini merupakan trik jitu dan cukup mudah seharusnya di terapkan oleh setiap calon guru. Karena dengan menerapkan keterampilan bertanya ini seorang pendidik dapat membaca kemampuan peserta didiknya sekaligus dapat mengarahkan peserta didik pada pembelajaran.

Selanjutnya keterampilan memberikan penguatan ini merupakan cara guru atau calon guru untuk mempertahankan perilaku positif peserta didik dengan memberi respon positif agar perilaku tersebut dapat di pertahankan, misal ada peserta didik yang berani tampil ke depan untuk bernyanyi atau menjawab pertanyaan dari guru, maka guru dapat memberi respon positif berupa pujian, sentuhan di kepala atau tepuk tangan yang memberi semangat, sehingga perilaku positif tersebut dapat dipertahankan bahkan menular pada peserta didik yang lain. Pada keterampilan ini ada 17 orang calon guru yang berhasil menerapkannya, sejatinya ini merupakan poin paling mudah untuk diterapkan, tapi ternyata masih ada calon guru yang bahkan bersikap abai pada tingkah laku posisif dari peserta didiknya hal ini dikarenakan calon guru masih belum bisa memposisikan dirinya sebagai guru tetapi sebagai mahasiswi yang sedang presentasi.

Selanjutnya keterampilan menggunakan variasi, keterampilan ini bertujuan untuk menghilangkan kebosanan dan kejenuhan pada peserta didik saat kegiatan belajar berlangsung, misal dengan mengajak peserta didik melakukan permainan singkat dengan melompat atau berteriak menyebutkan nama-nama benda atau hewan yang bisa di sesuaikan dengan tema, atau bisa juga mengajak peserta didik bernyanyi dan bisa dipilih lagu yang sesuai dengan tema. Keterampilan ini memang cukup sulit 
diterapkan dalam praktik ini mengingat mereka juga memiliki keterbatasan waktu jadi mahasiswi cukup terkendalam dalam menyesuiaikan variasi dengan tema yang dipilih sehingga banyak yang fokus pada tujuan pembelajaran saja, dan hanya 6 orang yang berhasil menerapkannya.

Keterampilan menjelaskan bertujuan agar sesuatu yang abstrak menjadi konkret dan nyata dimata peserta didik. Misal saat guru menjelaskan anggota tubuh guru bisa meminta salah satu peserta didik untuk berdiri di depan kelas dan yang lainnya diminta menyebutkan anggota tubuh yang di tunjuk guru, atau guru bisa membawa miniatur ke dalam kelas sesuai dengan tema yang akan di ajarkan. Keterampilan menjelaskan termasuk keterampilan yang juga cukup sulit diterapkan karena seorang guru atau calon pendidikan harus paham materi yang akan disampaikan dan mampu menjelaskan secara konkret (nyata) kepada peserta didik, karena pada dasarnya anak usia dini harus disuguhkan pada sesuatu yang nyata karena anak usia ada pada tahanpan berfikir konkret untukitu dibutuhkan media atau APE untuk membantu calon guru dalam menyampaikan dan menjelaskan materi, dan sayangnya hanya 8 orang calon guru yang menggunakan APE saat praktik. Gambar 2 menunjukkan beberapa contoh APE mahasiswi saat praktik.

Selanjutnya keterampilan membimbing kelompok kecil ini merupakan salah satu keterampilan yang penting untuk dikuasai calon pendidik yaitu bagaimana cara mengendalikan pengaturan yang berpusat pada peserta didik. Untuk keterampilan ini 11 orang calon guru berhasil menerapkannya dan ternyata semuanya memang telah memiliki pengalaman mengajar di TK dan PAUD,sedangkan yang lainnya belum mampu menerapkannya ada yang fokus pada beberapa atau kelompok tertentu saja 
sehingga mengabaikan kelompok yang lain dan ada yang tidak menerapkannya sama sekali.

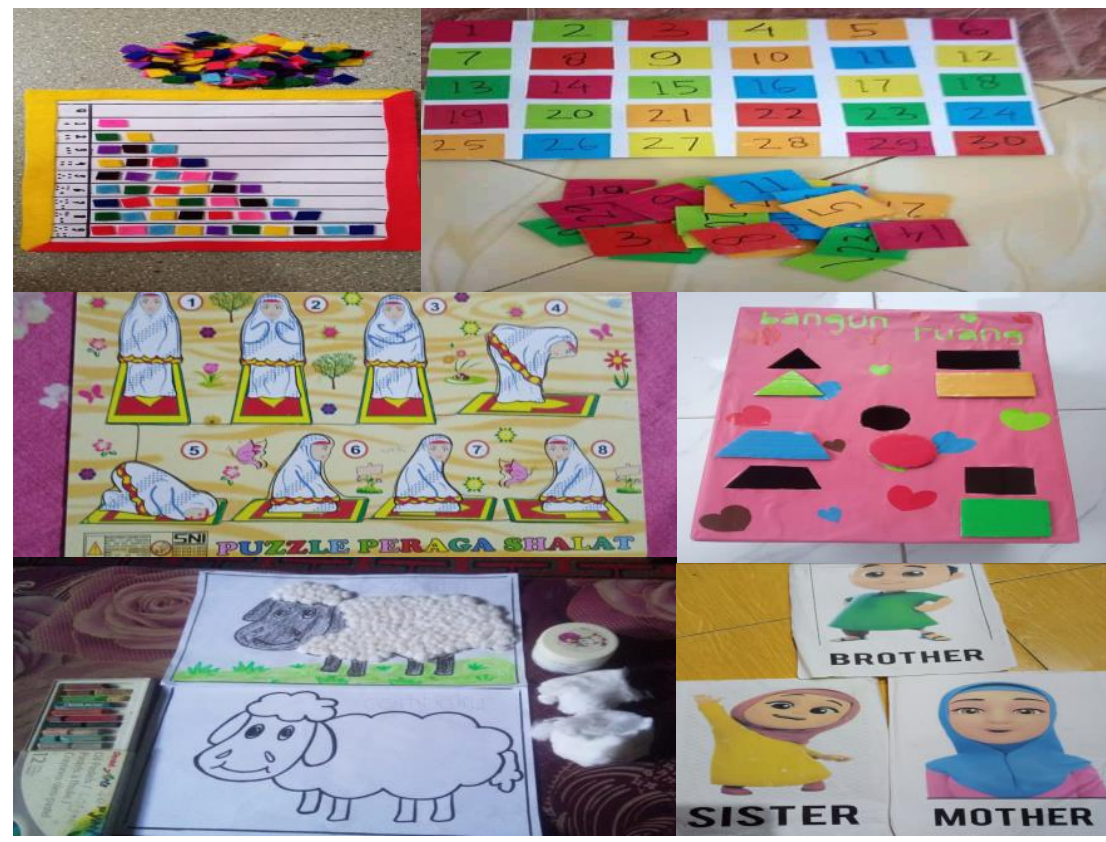

Gambar 2. Contoh APE Mahasiswi PAUD

Keterampilan Mengelolah kelas adalah tugas guru untuk memelihara atau menciptakan situasi kondisi kelas agar sesuai dan tujuan pembelajaran dapat tercapai. Ini termasuk keterampilan yang cukup sulit diterapkan dimana calon guru dihadapkan pada berbagai macam peserta didik dengan karakter yang unik dan calon guru harus mampu mengatasi kendala atau permasalahan yang muncul dari masing-masing karakter, maka kunci utamanya ada di keterampilan membukapelajaran dan hanya 8 orang yang berhasil menerapkannya, selebihnya gagal mengendalikan kelas saat ada peserta didik yang berperan pasif hingga super aktif, uncontrol hingga tidak mau melakukan tugas yang diberikan gurunya.

Terakhir keterampilan mengajar perorangan atau kelompok kecil tujuannya untuk menhidupkan suasan pembelajaran meski dengan siswa yang sedikit atau pun satu orang, diharapkan dalam keterampilan ini ada feedback atau pembelajaran 2 
arah. Hanya 8 orang calon guru yang mampu menghidupkan serta melakukan pembelajaran 2 arah, selebihnya justru tidak terjadi atau gagal menghidupkan suasana belajar dan tidak mendapatkan respon dari peserta didik.

Penguasaan terhadap keterampilan mengajar tersebut harus utuh dan terintegrasi, sehingga tercipta proses pembelajaran yang mengacu pada tujuan pembelajaran (Wulandari \& Kurniah, 2018). Karena itu pada kelas microteaching ini calon guru yakni mahasiswi PG PAUD semester VI benar-benar dituntut dapat menerapkan delapan keterampilan dasar mengajar tersebut. Setelah perform sesi I dengan segala masukan pada setiap penampilan calon guru terlihat banyak perubahan dan peningkatan seperti semakin banyak mahasiswi yang memberi masukan atau komentar saat salah satu rekannya selesai praktik yang artinya ada peningkatan pemahaman dari masing-masing mahasiswi, bahkan ada mahasiswi yang selesai perform mampu menganalisis kesalahannya atau kekurangan dari penampilannya. Peningkatan pemahaman ini terlihat pada Gambar 3, hasil perform II pada saat UAS.

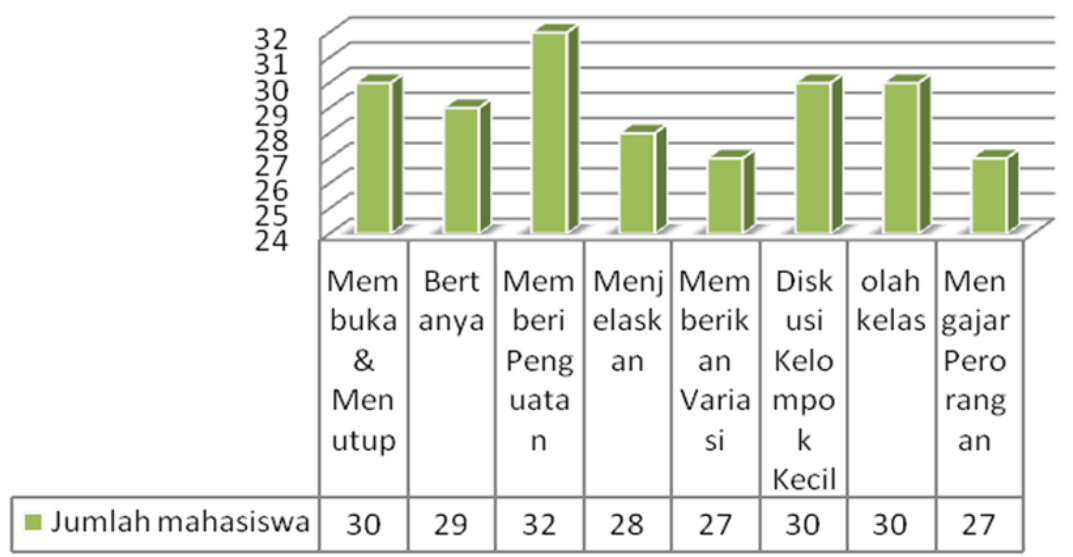

Gambar 3. Hasil Praktik II Microteaching Keterampilan Dasar Mengajar Mahasiswi PAUD

Gambar 3 menunjukkan peningkatan pemahaman Mahasiswi dalam pemahaman dan penerapan delapan keterampilan dasar mengajar menggunakan metode drill and practice. Pada praktik ke II hanya beberapa mahasiswi yang belum bisa menerapkan ke delapan 
keterampilan tersebut hal ini dikarenakan mereka belum bisa memanage waktu (mengontrol waktu) sehingga mereka kehabisan waktu dan materi belum selesai disampaikan, dan beberapa orang masih tampak nervouse sehingga antara apa yang direncanakan dengan yang dilakukan sedikit berbeda. Adapun perbandingan hasil praktik I dan II dapat dilihat pada diagram berikut:

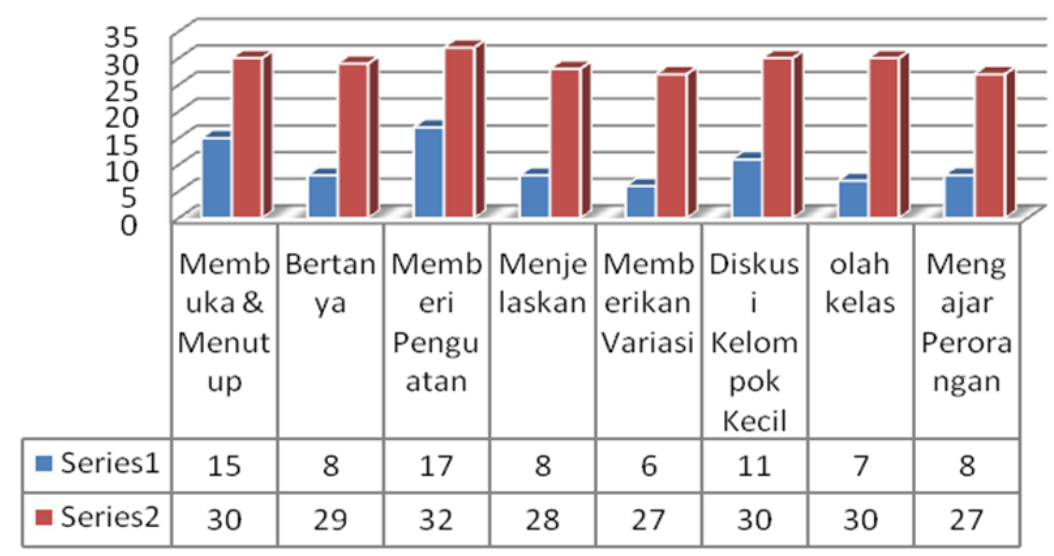

Gambar 4. Perbandingan Hasil Praktik I dan II Microteaching Keterampilan Dasar Mengajar Mahasiswi PAUD

Berdasarkan Gambar 4, terlihat peningkatan yang mencolok pada masing-masing keterampilan, pada keterampilan membuka dan menutup pembelajaran dari 15 orang menjadi 30 orang yang berhasil menerapkannya, dua orang calon guru tidak menerapkan ini karena terlihat nervouse di awal dan lupasaat mengimpulakn pembelajaran sebelum menutup kelas namun ini bisa diatasi dengan banyak berlatih, keterampilan bertanya dari 8 orang meningkat menjadi 29 orang, 3 orang yang belum menerapkan karena lupa dan memberikan pertanyaan yang tidak sesuai dengan tema yang di ajarkan. Keterampilan memberi penguatan berhasil dilakukan oleh semua calon guru tanpa kendala. Pada keterampilan menjelaskan ada peningkatan dari 8 orang menjadi 28 orang yang telah berhasil, sisanya belum berhasil karena kesulitan 
memilih bahasa yang tepat saat menjelaskan, beberapa memilih kata atau bahasa yang sulit di pahami oleh anak usia dini.

Menurut Mansur, pendidik yang terampil menyajikan pembelajaran akan menerangkan dengan kalimat bahasa yang baik dan benar yang memudahkan bagi peserta didik mengerti tentang permasalahan yang disampaikan dan ikut menampilkan gerakangerakan yang dapatmembantu kegiatan pembelajaran agar peserta didik memahami dan terampil terhadap mata pelajaranyang diajarkan, guru atau calon guru menyampaikan pertanyaan-pertanyaan dengan baik, memberikan penguatan dan mengadakan berbagai variasi dalam mengajar serta menghargai sikap dan perbuatan yang positif yang dilakukan peserta didik dalam pembelajaran (Mansur, 2017).

Keterampilan memberikan variasi terdapat peningkatan yang mencolok juga dari 6 orang meningkat menjadi 27 orang, sisanya belum mampu karena kehabisan waktu dan terlalu fokus pada keterampilan lain sehingga lupa menerapkan keterampilan memberikan variasi. Pada diskusi kelompok kecil dan mengajar perorangan masingmasing mengalami peningkatan dari 11 orang menjadi 30 dan dari 8 orang menjadi 27 orang, selebihnya belum berhasil karena tidak terjadi umpan balik pada kelompok kecil dan hanya fokus pada kelompok tertentu saja, sehingga kelompok lain terabaikan. Dan terkahir pada keterampilan mengelolah kelas dari 7 orang meningkat menjadi 27 orang, sisanya belum mampu mengelolah kelas karena belum bisa membuat peserta didik fokus di awal pembelajaran, belum bisa mengontrol peserta didik yang hiperaktif serta mengabaikan peserta didik yang tidak mengerjakan tugas sehingga mempengaruhi peserta didik lainnya, dan terlalu lama dalam menyiapkan APE yang digunakan sehingga kehilangan fokus peserta didik dan membuat pembelajaran menjadi kurang menarik. 
Hasil penelitian rekan dosen dari FKIP UNIB yang melakukan penelitian mengenai peningkatan keterampilan mengajar mahasiswa PAUD dengan metode drill yang hasilnya metode drill dapat meningkatkan keterampilan mengajar mahasiswa Semester V Prodi S1 Pendidikan Guru PAUD Fakultas Kependidikan dan Ilmu Pendidikan Universitas Bengkulu tahun ajaran 2019/2020. Peningkatan keterampilan mengajar mahasiswa mengalami peningkatan yang dikarenakan adanya proses pemahaman suatu materi secara mendalam mengenai kedelapan keterampilan mengajar, dilakukannya praktik secara langsung setiap mahasiswayang dilakukan di rumah maupun di kampus, dan pengembangan keterampilan yang dilakukan secara berulang-ulang setiap aspek keterampilan mengajar (Nasirun et al., 2020).

Sementara itu, hasil penelitian Safitri \& Sontani menunjukkan bahwa keterampilan mengajar guru dan motivasi belajar siswa baik secara parsial maupun simultan berpengaruh terhadap hasil belajar (Safitri \& Sontani, 2016). Secara parsial terdapat korelasi kuat antara keterampilan mengajar guru dan hasil belajar begitupun motivasi belajar siswa terhadap hasil belajar yang berkorelasi kuat. Demikian pula halnya dengan korelasi secara simultan antara keterampilan mengajar guru dan motivasi belajar siswa memiliki korelasi yang sama-sama kuat dimana terdapat besaran koefisien korelasi yang lebih besar dibandingkan secara parsial. Dari pengamatan ini dapat disimpulkan bahwa metode drill and practice dapat meningkatkan pemahaman mahasiswi PAUD semester VI mengenai keterampilan dasar mengajar.

\section{SIMPULAN}

Keterampilan dasar mengajar mahasiswi PGPAUD semester VI tahun ajaran 20202021 pada kelas Microteaching mengalami peningkatan setelah menerapkan metode driil 
and practice. Dalam penerapan metode drill and practice ini mahasiswi tidak hanya diberi penjelasan mengenai materi keterampilan dasar mengajar semata tapi diberikan latihan (practice) secara berulang sehingga para mahasiswi mampu menerapkan dan memperoleh pemahaman mendalam mengenai keterampilan dasar mengajar. Peningkatan ini terjadi dikarenakan adanya proses latihan (praktik) yang dilakukan secara berulang dan adanya evaluasi atau refleksi dari setiap mahasiswi yang tampil, serta adanya contoh nyata dan langsung yang dihadapakan pada mereka sehingga hal ini mampu mengembangkan setiap aspek keterampilan dasar mengajar pada masing-masing mahasiswi. Sebagai saran dan masukan bakwa metode driil and practice ini dapat diterapkan pada setiap mata kuliah yang membutuhkan pemahaman tinggi atau mendalam, terlebih di masa pandemic saat ini dimana terjadi pembatasan pembelajaran secara tatap muka, sehingga berdampak pada penyampaian materi secara langsung yang dapat mengakibatkan kesalah pemahaman, namun dengan menerpakan metode ini mahasiswa-mahasiswi dapat mengasah keterampilan dan pemahamannya dengan banyak latihan di rumah atau dimana saja tanpa terbats waktu tatap muka perkuliahan.

\section{DAFTAR PUSTAKA}

Adnyana, P. B. (2018). Pola Pelaksanaan Microteaching. LPPPM-LABDIKDU Uiversitas Pendidikan Ganesha.

Aida, W. (2019). Analisis Kemampuan Keterampilan Dasar Mengajar (Micro Teaching) Mahasiswa Angkatan I Program Studi Pendidikan IPS Fakultas Keguruan Dan Ilmu Pendidikan Universitas Pasir Pengaraian. Jurnal Edu Research, 8(2), 1-10.

Asia, N. (2019). Penerapan Keterampilan dasar Mengajar Guru di SMP Muhammadiyah Soni Dampal Selatan. Scolae, 2(1), 253-261.

Elprida, S. K., Sujana, I. W., Tirtayani, L. A., \& Psi, S. (2018). Pengaruh keterampilan dasar mengajar guru terhadap perilaku disiplin pada anak usia dini kelompok B. Jurnal Pendidikan Anak Usia Dini Undiksha, 6(1), 11-20.

Helmiati. (2013). Micro Teaching. Aswaja Pressindo. 
M. R. Wahyulestari. (2018). Keterampilan Dasar Mengajar di Sekolah Dasar. Seminar Nasional Pendidikan Era Revolusi, 199-210.

Mansur, N. (2017). Penerapan Keterampilan Mengajar Dalam Upaya Pencapaian Hasil Belajar Mahasiswa. Lantanida Journal, 4(2), 118-127.

Mansyur, M. (2017). Keterampilan Dasar Mengajar dan Penguasaan Kompetensi Guru (suatu Proses Pembelajaran Micro). El-Ghiroh: Jurnal Studi Keislaman, 12(1), 130147.

Nasirun, M., Yulidesni, Y., \& Daryati, M. E. (2020). Peningkatan Keterampilan Mengajar Mahasiswa pada Anak Usia Dini melalui Metode Drill. Jurnal Obsesi: Jurnal Pendidikan Anak Usia Dini, 5(1), 441-451.

Rusmaini. (2019). Kemampuan Dasar Mengajar (S. Anwar, Ed.). Unpam Press.

S. Shoffa. (2016). Keterampilan Dasar Mengajar (Suher \& I. Fatin, Eds.; 1st ed.). Mavendra Pers.

Safitri, E., \& Sontani, U. T. (2016). Keterampilan mengajar guru dan motivasi belajar siswa sebagai determinan terhadap hasil belajar. Jurnal Pendidikan Manajemen Perkantoran (JPManper), 1(1), 144-153.

Wulandari, Y., \& Kurniah, N. (2018). KEMAMPUAN GURU DALAM MELAKSANAKAN KETERAMPILAN MENJELASKAN (Di TK Witri 2 Kota Bengkulu). Jurnal Ilmiah Potensia, 3(1), 49-53. 